\title{
Biokontrol arbuscular mycorrhizal fungi (AMF) Glomus spp. terhadap infeksi Fusarium oxysporum Schlecht et Fr. pada tanaman cabai rawit (Capsicum frutescens $\mathrm{L}$.)
}

\author{
Arbuscular mycorrhizal fungi (AMF) Glomus spp. as bio-control of Fusarium \\ oxysporum Schlecht et Fr. infection in chilli plants (Capsicum frutescens L.)
}

\author{
Ni Putu Muni Raisani ${ }^{1 *}$, Meitini Wahyuni Proborini ${ }^{3}$, Ni Luh Suriani ${ }^{2}$, Eniek Kriswiyanti ${ }^{2}$ \\ 1) Program Magister Ilmu Biologi, Fakultas MIPA, Universitas Udayana \\ 2) Program Studi Biologi, Fakultas MIPA, Universitas Udayana \\ 3) Program Doktor Biologi, Fakultas MIPA, Universitas Udayana \\ *Email: munierlan@gmail.com
}

Diterima 21 Desember 2019 Disetujui 29 Mei 2020

\section{INTISARI}

Fusarium oxysporum Schlecht et Fr. merupakan patogen tular tanah yang dapat menyebabkan layu fusarium pada cabai rawit. Penggunaan Fungi Mikoriza Arbuskula (FMA) sebagai simbion dapat meningkatkan ketahanan tanaman terhadap infeksi jamur pathogen F.oxysporum. Penelitian ini bertujuan untuk mengetahui pengaruh FMA sebagai biokontrol pertumbuhan tanaman cabai rawit terhadap infeksi $F$. oxysprum serta efektivitas pemberian FMA untuk menurunkan intensitas serangan penyakit layu fusarium. Bibit cabai rawit ditumbuhkan pada media tanah steril (kontrol negatif), tanah steril dan $10 \mathrm{ml}$ patogen (kontrol positif), tanah steril dan FMA $100 \mathrm{~g}$, FMA $100 \mathrm{~g}$ dan $10 \mathrm{ml}$ patogen, tanah steril dan $200 \mathrm{~g}$ FMA, FMA $200 \mathrm{~g}$ dan $10 \mathrm{ml}$ patogen, tanah steril dan $300 \mathrm{~g}$ FMA dan $10 \mathrm{ml}$ patogen. Hasil penelitian menunjukkan bahwa pemberian 200 g spora FMA menunjukkan pengaruh berbeda nyata pada tinggi tanaman, jumlah daun, berat kering akar dan berat kering tajuk tanaman cabai rawit berumur tiga bulan. Sedangkan inokulasi $300 \mathrm{~g}$ FMA memberikan hasil terbaik pada buah cabai dan persentase kolonisasi FMA sebesar 84, 45\%. Inokulasi 300 g FMA menurunkan infeksi $F$. oxysporum saat 30 Hari Setelah Tanam (HST) sebesar 3.36\%. Kesimpulan dari riset ini menunjukkan inokulasi FMA Glomus spp. mampu meningkatkan tinggi tanaman, jumlah daun, berat kering akar dan berat kering tajuk, kecepatan berbunga dan ketahanan tanaman terhadap infeksi jamur $F$. oxysporum.

Kata kunci: Inokulasi, suspensi spora Glomus spp., penyakit, ketahanan

\begin{abstract}
Fusarium oxysporum Schlecht et Fr. is a soil-borne pathogen that can cause fusarium wilt in chili plants. The use of Arbuscular Mycorrhizal Fungi (AMF) as a symbiont can increase plant resistance to fungal $F$. oxysporum infection. This study aims to determine the effect of AMF as a biocontrol of chili plant growth against $F$. oxysprum infection and the effectiveness of AMF administration to reduce the intensity of fusarium wilt disease. The research methods are as follows: Chili seeds are grown on sterile soil media (negative control), sterile soil and $10 \mathrm{ml}$ pathogens (positive control), sterile soil and $100 \mathrm{~g} \mathrm{AMF}, 100 \mathrm{~g}$ AMF and $10 \mathrm{ml}$ pathogens, sterile soil and $200 \mathrm{~g} \mathrm{AMF}, 200 \mathrm{~g}$ FMA and $10 \mathrm{ml}$ pathogens, sterile soil and $300 \mathrm{~g}$ FMA $300 \mathrm{~g}$ AMF and $10 \mathrm{ml}$ pathogens. The results showed that inoculation of $200 \mathrm{~g}$ of AMF spores showed significantly different effects on plant height, number of leaves, root dry weight and shoot dry
\end{abstract}


weight of three-month old chili plants. Whereas the $300 \mathrm{~g}$ AMF inoculation gave the best results on chili and the percentage of AMF colonization was 84, 45\%. Inoculation of $300 \mathrm{~g}$ AMF reduced $F$. oxysporum infection at 30 days by $3.36 \%$. The conclusion of this research shows that the inoculation of AMF Glomus spp. can increase plant height, number of leaves, root dry weight and shoot dry weight, flowering speed and plant resistance to F.oxysporum fungal infections.

\section{Keywords: Inoculation, fungal suspension, disease, endurance}

\section{PENDAHULUAN}

Cabai (Capsicum annuum L.) termasuk salah satu komoditi pertanian yang mempunyai nilai ekonomi yang cukup tinggi. Buah cabai muda mengandung vitamin $\mathrm{A}, \mathrm{C}$ dan $\mathrm{E}$, sedangkan yang sudah masak selain mengandung vitamin $\mathrm{C}$ dapat dipakai sebagai bumbu masak atau bahan pembuatan saus (Djawarningsih, 2005). Kebutuhan cabai di Indonesia dari tahun ke tahun terus mengalami peningkatan namun produktivitasnya mengalami penurunan. Tahun 2016 sebesar 8, 47 ton/ha, sedangkan pada tahun 2017 produktivitasnya menurun 8,46 ton/ha, mengalami penurunan $(0,13 \%)$ (Kementerian Pertanian RI 2018). Salah satu faktor yang menyebabkan penururan produktifitas adalah gangguan penyakit (Duriat et al., 2007).

Salah satu penyakit tanaman cabai adalah layu fusarium yang disebabkan oleh jamur Fusarium oxysporum Schlecht et Fr. Jamur tersebut dapat menyebabkan kelayuan pada tanaman yang masih muda atau bahkan yang sudah produktif (Akaeze and Aduramigba-Modupe, 2017). Para petani umumnya lebih memilih menggunakan pestisida kimiawi (Wandani et al., 2015) namun penggunaan dalam jangka waktu lama berdampak negatif terhadap mahkluk hidup dan lingkungan (Aktar et al., 2009) sehingga diperlukan pestidida nabati sebagai alternatif yang ramah lingkungan.

\section{Smith dan Read (2008) Fungi Mikoriza} Arbuskula (FMA) merupakan salah satu mikroorganisme komponen rizosfer yang mampu meningkatkan pertumbuhan serta berkorelasi positif terhadap fisiologi tanaman inang untuk menurunkan intensitas penyakit. Hasanah et al. (2017), menyebutkan bahwa pemberian FMA pada tanaman tomat (Solanum lycopersicum) berpengaruh nyata terhadap masa inkubasi penyakit layu fusarium. Penelitian dari Imron et al. (2015), penggunaan FMA pada tanaman cabai mampu menunda kemunculan penyakit daun keriting kuning pada cabai yang diakibatkan oleh Begomovirus.

Penelitian tentang peranan FMA Glomus spp. di Bali telah dilakukan pada tanaman kedelai sebagai pupuk hayati dengan hasil menunjukkan bahwa aplikasi FMA mampu meningkatkan pertumbuhan dan produktifitas tanaman kedelai (Masfufah et al., 2014 ; Hakiki, 2013; Triatna, et al., 2019). Selain itu FMA Glomus juga dapat digunakan sebagai agen biokontrol tanaman jagung terhadap penyakit oleh jamur Curvularia sp (Windrasari, et al.,2019) namun belum pernah dilakukan penelitian tentang peranan FMA sebagai biokontrol terhadap infeksi pathogen tanaman cabai rawit sehingga penelitian ini dilakukan untuk menguji efektifitas FMA dalam mengontrol infeksi patogen $F$. oxysporum pada cabai rawit.

\section{MATERI DAN METODE}

\section{Rancangan Percobaan}

Penelitian menggunakan rancangan acak kelompok (RAK) 2 faktorial. Faktor I adalah konsentrasi spora FMA (0, 100, 200 dan 300 g), faktor II adalah konsentrasi patogen $F$. oxysporum Schlecht et Fr. (0 dan $10 \mathrm{ml}$ ), sehingga diperoleh 8 kombinasi perlakuan. Jumlah total polibag tanaman uji adalah 72 (8 perlakuan $\mathrm{x} 3$ ulangan $\mathrm{x}$ 3 unit).

\section{Isolasi patogen $F$. oxysporum Schlecht et Fr.}

Akar tanaman cabai rawit yang menunjukkan gejala daun tanaman berwarna kuning kecokelatan dipotong sepanjang $\pm 1 \mathrm{~cm}$ dan disterilasi, diinkubasi selama $5 \times 24$ jam pada 
media Potato Dekstrosa Agar (PDA). Selanjutnya direisolasi hingga diperoleh isolat jamur yang diduga sebagai penyebab layu pada tanaman cabai

\section{Penyaringan spora FMA}

Penelitian menggunakan stok spora FMA hasil perbanyakan di greenhouse Program Studi Biologi F. MIPA Universitas Udayana Bali. Spora FMA diisolasi dan disaring menggunakan metode penyaringan basah (Brundreet et al., 2008). Spora yang dikumpulkan disimpan di refrigrator untuk penelitian di greenhouse.

\section{Persentase kolonisasi FMA pada akar tanaman}

Akar serabut tanaman cabai dipotong dengan ukuran $\pm 2 \mathrm{~cm}$ sebanyak 15-20 potong akar. Selanjutnya akar diproses dengan prosedur bertahap yang meliputi tahap clearing, staining, dan destaining yang dimodifikasi (Proborini et al, 2011; Masfufah et al., 2016).

Kolonisasi FMA pada akar dihitung dengan menggunakan metode slide yang dimodifikasi (Proborini, 2011; Masfufah et al., 2016). Persentase kolonisasi dilihat dengan kriteria yaitu: 0-5\% (sangat rendah), 6-25\% (rendah), 26$50 \%$ (sedang), $51-75 \%$ (tinggi), dan 76-100\% (sangat tinggi) (Setiadi, 2003). Perhitungan persentase kolonisasi FMA pada akar menggunakan rumus:

$\%$ kolonisasi $=\frac{\text { Jumlah akar terinfeksi }(+)}{\text { Jumlah akar yang diamati }} \times 100 \%$

\section{Persiapan media tanam}

Media tanah latozol dan pasir dengan perbandingan 1:1 disterilisasi dengan cara dikukus selama $1 \mathrm{jam}$, suhu $\pm 100^{\circ} \mathrm{C}$. Kemudian dimasukkan ke dalam polybag ukuran $15 \times 50 \mathrm{~cm}$ sebanyak $5 \mathrm{~kg}$ tanah pada masing-masing polybag.

\section{Inokulasi FMA dan jamur patogen}

Campuran tanah dan pasir yang sudah steril di polybag dilubangi sedalam $5 \mathrm{~cm}$ untuk meletakkan spora FMA dan tanaman yang sudah memiliki 4 daun (umur \pm 2 minggu). Inokulasi jamur pathogen $F$.oxysporum dilakukan pada saat tanaman berumur 30 hari setelah dipindahkan ke polybag.

\section{Variabel yang diamati}

Variabel yang diamati adalah tinggi tanaman, jumlah daun, berat kering tanaman (akar dan tajuk), berat dan jumlah buah cabai, persentase kolonisasi FMA dan efektivitas FMA terhadap serangan $F$. oxysporum Schlecht et Fr. Tinggi tanaman $(\mathrm{cm})$, dihitung dari pangkal batang hingga ujung daun terpanjang pada umur 10, 20, 30, 40, 50 dan 60 hari. Jumlah daun, pada umur 10, 20, 30, 40, 50 dan 60 hari. Bobot kering tanaman diukur setelah penelitian akhir (60 HST) dan dioven selama 48 jam pada suhu $60^{\circ} \mathrm{C}$ (sampai berat konstan).. Persentase derajat infeksi endomikoriza pada akar tanaman cabai (Capsicum annuum L.) diamati pada akhir penelitian. Persentase perkembangan patogen diamati selama 30 hari setelah infeksi (HSI). Data dianalisis secara statistik menggunakan Analisa of Variant (ANOVA), bila diantara perlakuan terdapat perbedaan nyata dilanjutkan uji Duncan's 5\%.

Intensitas serangan penyakit dihitung dengan menggunakan skala 0 sampai 5 (Aulia et al., 2016), yaitu: 0 (tidak ada layu), 1 (satu daun layu), 2 (dua atau tiga daun layu), 3 (semua daun layu kecuali daun ke-2 dan ke-3 dari pucuk), 4 (semua daun layu), dan 5 (tanaman mati). Nilai intensitas penyakit ditentukan dengan rumus (Aulia et al., 2016):

IS $=\frac{\sum(n \times v)}{N \times Z} \times 100 \%$

Keterangan:

IS: intensitas serangan

$\mathrm{n}$ : jumlah daun pada skala ke-i

$\mathrm{v}$ : skala ke-i

$\mathrm{N}$ : jumlah total daun setiap tanaman

$\mathrm{Z}$ : skala tertingg

Penilaian tingkat intensitas penyakit jamur $F$. oxysporum. pada tanaman cabai rawit (Sinaga, 2003), yaitu $0 \%$ (imun), $1 \%$ - 25\% (resisten), 
$26 \%-50 \%$ (agak resisten), 51\% - 75\% (agak rentan), dan $76 \%$ - 100\% (rentan).

\section{HASIL}

Hasil penelitian menunjukkan bahwa inokulasi spora FMA pada tanaman cabai rawit menunjukkan pengaruh yang nyata $(\mathrm{P}<0,05)$ terhadap tinggi tanaman, jumlah daun, berat kering akar, berat kering tajuk, berat dan jumlah buah, persentase kolonisasi FMA dan intensitas serangan penyakit. Berdasarkan analisis statistik perlakuan pemberian FMA 200 gram dan 300 g menunjukkan hasil berbeda nyata dibandingkan dengan kontrol terhadap parameter tinggi tanaman, berat kering tajuk tanaman cabai umur 60 hari.

Pada berat kering akar tanaman perlakuan 200 g dan 300 g spora FMA menunjukkan hasil berbeda nyata dengan kontrol. Perlakuan menunjukkan hasil berbeda nyata $(\mathrm{P}<0,05)$ dengan kontrol positif pada jumlah daun tanaman.
Persentase kolonisasi FMA terdapat perbedaan yang nyata antara perlakuan dibandingkan dengan kontrol (Tabel 1). Tanaman yang diinokulasi FMA pada perlakuan P5 (Spora 200 g) dan P6 (spora 300 g) memiliki kolonisasi FMA tertinggi dibandingkan dengan perlakuan lainnya dan kontrol.

Hasil penelitian menunjukkan bahwa pemberian spora FMA 100 g, 200 g, dan 300 g FMA pada tanaman cabai rawit yang terinfeksi patogen menunjukkan pengaruh nyata terhadap kontrol positif pada 20-30 HSI (Gambar 1). Pada 20-30 HSI intensitas serangan penyakit pada control positif, kontrol positif dengan nilai intensitas serangan berturut-turut sebesar $21,76 \%$ dan 27,12\% lebih tinggi dibandingkan dengan perlakuan inokulasi FMA 100 g, $200 \mathrm{~g}$ dan $300 \mathrm{~g}$. Simbiosis FMA dengan akar tanaman cabai rawit ditunjukkan dengan adanya hifa arbuskular, vesikel pada akar tanaman yang telah diwarnai dengan Methylen Blue (Gambar 2).

Tabel 1. Rata-rata tinggi tanaman, berat kering akar, berat kering tajuk, jumlah daun, berat buah, jumlah buah dan kolonisasi AMF

\begin{tabular}{cccccccc}
\hline Perlakuan & $\begin{array}{c}\text { Tinggi } \\
\text { Tanaman } \\
(\mathbf{c m})\end{array}$ & $\begin{array}{c}\text { Berat Kering } \\
\text { Akar } \\
\text { Tanaman }(\mathbf{g})\end{array}$ & $\begin{array}{c}\text { Berat Kering } \\
\text { Tajuk } \\
\text { Tanaman }(\mathbf{g})\end{array}$ & $\begin{array}{c}\text { Jumlah } \\
\text { daun } \\
(\text { helai) }\end{array}$ & $\begin{array}{c}\text { Berat } \\
\text { Buah } \\
(\mathbf{g})\end{array}$ & $\begin{array}{c}\text { Jumlah } \\
\text { Buah }\end{array}$ & $\begin{array}{c}\text { Kolonisasi } \\
\text { AMF }(\%)\end{array}$ \\
\hline K1 & $28,83 \pm 2,31 \mathrm{a}$ & $3,61 \pm 1,21 \mathrm{ab}$ & $5,16 \pm 1,26 \mathrm{a}$ & $23,89 \pm 5,64 \mathrm{ab}$ & $1,52 \pm 2,63 \mathrm{a}$ & $1,00 \pm 1,73 \mathrm{a}$ & $0 \pm 0.00 \mathrm{a}$ \\
K2 & $31,64 \pm 1,76 \mathrm{ab}$ & $2,70 \pm 0,43 \mathrm{a}$ & $5,14 \pm 0,28 \mathrm{a}$ & $17.33 \pm 1,86 \mathrm{a}$ & $0,54 \pm 0,93 \mathrm{a}$ & $0,44 \pm 0,77 \mathrm{a}$ & $0 \pm 0.00 \mathrm{a}$ \\
P1 & $31.86 \pm 0,75 \mathrm{ab}$ & $5,61 \pm 1,04 \mathrm{bc}$ & $8,15 \pm 0,44 \mathrm{ab}$ & $26.89 \pm 4,52 \mathrm{ab}$ & $3,51 \pm 1,01 \mathrm{a}$ & $2,00 \pm 1,20 \mathrm{a}$ & $70.37 \pm 3.39 \mathrm{~b}$ \\
P2 & $33.42 \pm 1,41 \mathrm{abc}$ & $4,76 \pm 0,76 \mathrm{bc}$ & $7,87 \pm 1,47 \mathrm{ab}$ & $26.22 \pm 5,17 \mathrm{ab}$ & $4,23 \pm 2,43 \mathrm{a}$ & $2,22 \pm 1,39 \mathrm{a}$ & $66.66 \pm 5.88 \mathrm{~b}$ \\
P3 & $41.87 \pm 10,37 \mathrm{~cd}$ & $6,48 \pm 1,57 \mathrm{c}$ & $11,71 \pm 3,71 \mathrm{~b}$ & $32.56 \pm 3,69 \mathrm{~b}$ & $5,8 \pm 3,56 \mathrm{ab}$ & $3,00 \pm 2,34 \mathrm{a}$ & $70.37 \pm 2.56 \mathrm{~b}$ \\
P4 & $46.68 \pm 6,66 \mathrm{~d}$ & $5,22 \pm 0,47 \mathrm{bc}$ & $10,47 \pm 1,96 \mathrm{~b}$ & $23.00 \pm 3,46 \mathrm{ab}$ & $3,73 \pm 2,81 \mathrm{a}$ & $2,22 \pm 1,65 \mathrm{a}$ & $69.63 \pm 3.39 \mathrm{~b}$ \\
P5 & $38.90 \pm 1,94 \mathrm{bcd}$ & $6,32 \pm 1,90 \mathrm{c}$ & $8,98 \pm 3,37 \mathrm{ab}$ & $26.22 \pm 8,00 \mathrm{ab}$ & $11,27 \pm 4,03 \mathrm{~b}$ & $7,11 \pm 2,04 \mathrm{~b}$ & $83.70 \pm 6.79 \mathrm{c}$ \\
P6 & $36.92 \pm 3,13 \mathrm{abc}$ & $5,22 \pm 0,16 \mathrm{bc}$ & $8,81 \pm 0,19 \mathrm{ab}$ & $27.45 \pm 9,24 \mathrm{ab}$ & $11,98 \pm 6,57 \mathrm{~b}$ & $6,67 \pm 3,52 \mathrm{~b}$ & $84.45 \pm 3.85 \mathrm{c}$ \\
\hline
\end{tabular}

Keterangan:

1. (K1) tanah steril/kontrol negatif;(K2) tanah steril+patogen $10 \mathrm{ml} /$ kontrol positif;

(P1) AMF $100 \mathrm{~g}+$ tanah steril; (P2) AMF $100 \mathrm{~g}+$ patogen $10 \mathrm{ml}$;

(P3) AMF $200 \mathrm{~g}+$ tanah steril; (P4) AMF $200 \mathrm{~g}+$ patogen $10 \mathrm{ml}$;

(P5) AMF $300 \mathrm{~g}+$ tanah steril; (P6) AMF $300 \mathrm{~g}+$ patogen $10 \mathrm{ml}$.

2. Nilai yang diikuti oleh abjad yang sama pada kolom yang sama tidak berbeda nyata $(\mathrm{P}>0,05)$. 


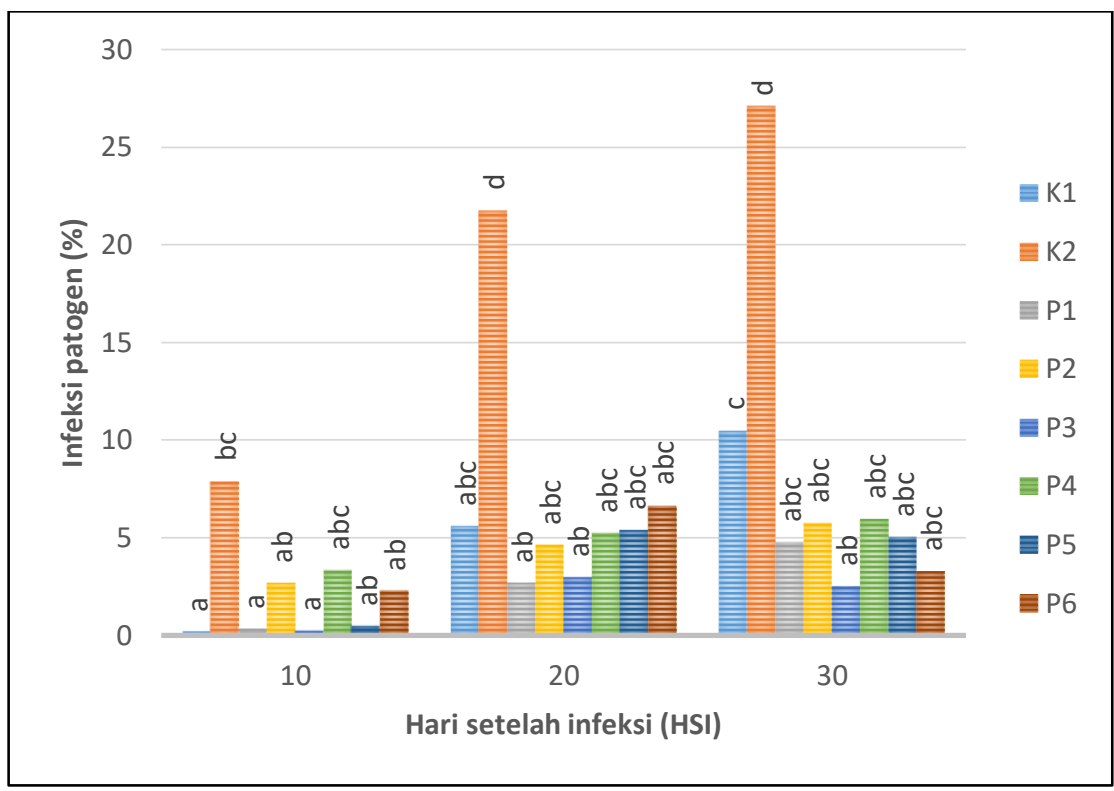

Gambar 1. Intensitas serangan penyakit pada setiap perlakuan

1. (K1) tanah steril/kontrol negatif;(K2) tanah steril+patogen $10 \mathrm{ml} /$ kontrol positif;

(P1) AMF $100 \mathrm{~g}+$ tanah steril; (P2) AMF $100 \mathrm{~g}+$ patogen $10 \mathrm{ml}$;

(P3) AMF $200 \mathrm{~g}+$ tanah steril; (P4) AMF $200 \mathrm{~g}+$ patogen $10 \mathrm{ml}$;

(P5) AMF $300 \mathrm{~g}+$ tanah steril; (P6) AMF $300 \mathrm{~g}+$ patogen $10 \mathrm{ml}$.

2. Notasi yang sama menunjukkan berbeda tidak nyata $(\mathrm{P}>0,05)$.

3.
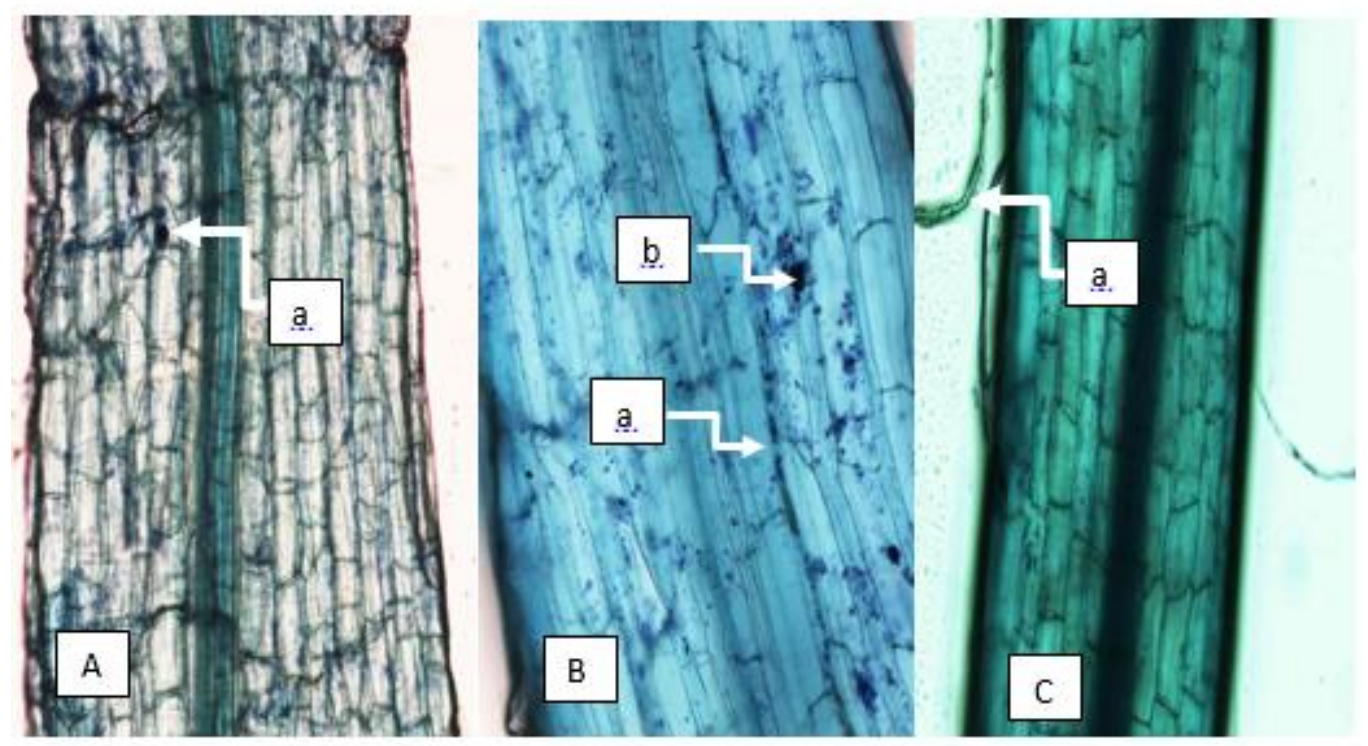

Gambar 2. Kolonisasi AMF pada akar cabai rawit (A) akar cabai yang menunjukkan vesikel (a) perbesaran 100x; (B) hifa internal (a) arbuskular (b) perbesaran 200x; (C) hifa eksternal (a) pada akar cabai rawit perbesaran $100 \mathrm{x}$

\section{PEMBAHASAN}

Inokulasi FMA pada cabai rawit memberikan hasil berbeda nyata $(\mathrm{P}<0,05)$ pada tinggi tanaman, jumlah daun, berat kering akar, berat kering tajuk, berat dan jumlah buah, persentase kolonisasi FMA dan intensitas serangan penyakit. Hal ini karena pemberian FMA pada tanaman cabai rawit dapat meningkatkan penyerapan unsur hara yang dibutuhkan oleh tanaman. Tinggi tanaman yang 
dihasilkan pada inokulasi 200 g FMA memberikan hasil tertinggi tanaman cabai umur 60 hari dan berbeda nyata dengan kontrol hal ini menunjukkan unsur P yang terdapat dalam FMA dapat berperan secara fungsional dalam pembentukan fosfolipid pada membran sel tanaman sehingga proses tersebut sangat berpengaruh dalam pertambahan tinggi tanaman (Jamilah et al., 2016). Selain itu inokulasi FMA mampu meningkatkan produksi hormon pertumbuhan tanaman seperti auksin, sitokinin dan giberelin dimana hormone-hormon tersebut yang berperan dalam pembelahan dan pemanjangan sel (Hakiki, 2013).

Inokulasi 200 g FMA pada cabai rawit memberikan hasil tertinggi pada jumlah daun sebanyak 32, 56 helai, terendah pada kontrol positif sebanyak 17, 33 helai daun. Hal ini menunjukkan bahwa pemberian FMA mampu meningkatkan penyerapan unsur hara terutama unsur $\mathrm{P}$ yang sangat penting bagi pertumbuhan tanaman (Jamilah et al., 2016), sehingga meningkatkan hasil asimilat yang digunakan dalam pembentukan daun (Putri et al., 2016). Daun yang dihasilkan pada kontrol positif lebih sedikit karena tanpa adanya inokulasi FMA tanaman menjadi lebih rentan terhadap penyakit layu fusarium. FMA dapat meningkatkan ketahanan tanaman terhadap serangan patogen (Imron et al., 2015).

Berat kering tanaman mencermikkan pertumbuhan tanaman dan banyaknya unsur hara yang terserap (Musfal, 2010). Pemberian spora FMA sebanyak 200 g dan 300 g FMA memberikan pengaruh yang nyata terhadap bobot kering akar dan bobot kering tajuk hal ini sesuai dengan hasil dengan pengukuran tinggi tanaman cabai (Tabel 1). Menurut Prasasti et al. (2013), tanaman yang memiliki pertumbuhan tinggi dan diameter batang yang baik menghasilkan berat kering tanaman yang tinggi. Tanaman memerlukan unsur hara yang cukup dalam melakukan berbagai proses metabolisme salah satunya yaitu proses fotosintesis (Hasbiah dan Wahidah, 2013). Proborini (2011), menyatakan bahwa tanaman yang berfotosintesis dengan aktif akan memberikan pengaruh yang positif terhadap penambahan jumlah daun, berat tanaman, berat akar, dan tajuk, sehingga tanaman yang terkolonisasi mikoriza memiliki jumlah daun bobot tanaman yang lebih tinggi dibandingkan tanaman yang tidak terkolonisasi mikoriza.

Pemberian 300 g FMA terhadap parameter berat buah dan jumlah buah menunjukkan hasil yang berbeda dengan kontrol (Tabel 1). Hal ini karena FMA yang mengkolonisasi akar menghasilkan hifa eksternal (Gambar 2 C) yang dapat meningkatkan kapasitas akar dalam penyerapan air dan unsur hara, terutama fosfat (Prasasti et al., 2013). Menurut Aulia et al. (2016), FMA mampu menguraikan unsur P yang terikat dalam tanah agar dapat diserap oleh akar tanaman, sedangkan tingginya serapan $\mathrm{P}$ oleh tanaman yang terinfeksi FMA disebabkan oleh hifa FMA mengeluarkan enzim fosfatase sehingga $\mathrm{P}$ yang terikat di dalam tanah akan terlarut dan tersedia bagi tanaman.

Menurut Campbell et al. (2002), fosfor merupakan bagian integral tanaman yang berperan pada proses penyimpanan (storage) dan pemindahan energi. Fosfor digunakan dalam pembentukan ATP yang merupakan kompleks molekul berenergi tinggi. ATP dihasilkan melalaui proses fotofosforilasi pada reaksi terang fotosintesis yang digunakan oleh tumbuhan pada proses pembentukan glukosa dari molekul $\mathrm{CO}_{2}$ dan $\mathrm{H}_{2} \mathrm{O}$. Hasil fotosintesis kemudian digunakan dalam respirasi sel untuk menghasilkan ATP. Energi yang disimpan dalam bentuk pati digunakan untuk pembentukan tunas, akar, bunga, buah dan proses pertumbuhan tanaman lainnya. Menurut Aulia et al. (2016), unsur P diperlukan tanaman dalam pembentukan bunga dan buah. Hasil penelitian ini didukung hasil penelitian oleh Mila et al. (2016), menyatakan bahwa pemberian FMA mampu meningkatkan berat basah buah cabai paprika pertanaman. Buah yang dihasilkan pada kontrol lebih sedikit karena tanpa adanya inokulasi FMA tanaman menjadi lebih rentan terhadap penyakit layu fusarium. Menurut Agrios (2005), F. oxysporum mampu mensekresi zat toksin berupa asam fusarik, dan asam dehidrofusarik yang mampu menghambat proses fotosintesis. Wandani et al (2015), 
menambahkan dengan terganggunya proses fotosintesis maka glukosa sebagai penyusun utama buah juga tidak dihasilkan secara maksimal dan menurunkan biomassa buah cabai.

Hasil pengamatan persentase kolonisasi FMA pada akar tanaman cabai (Tabel 1) menunjuk semakin tinggi dosis FMA yang digunakan, maka semakin tinggi derajat infeksi FMA pada perakaran tanaman. Hal ini sesuai dengan penelitian Jamilah et al. (2016), semakin tinggi FMA yang diinokulasikan pada tanaman maka semakin tinggi pula persentase kolonisasi FMA pada perakaran. Pada kontrol tidak ditemukan adanya kolonisasi FMA pada akar tanaman cabai rawit karena media tanam yang digunakan telah disterilisasi, sehingga spora FMA dan mikrooorganime yang terdapat pada media tanam dorman. Gambar 1 menunjukkan bahwa FMA berperan dalam mengurangi intensias penyakit. Pada kontrol terlihat memiliki intensitas penyakit yang lebih tinggi dibandingkan dengan perlakuan lainnya. Menurut Agrios (2005), kondisi lingkungan yang mendukung pertumbuhan tanaman dan kurang mendukung bagi perkembangan patogen memperlambat masa inkubasi, sehingga patogen memerlukan waktu lebih lama untuk menginfeksi tanaman. Tanaman yang tidak diinokulasi AMF memiliki panjang xilem diskolorasi yang berbeda nyata dengan tanaman yang diinokulasi AMF. Menurut Alfizar et al. (2011), semakin cepat masa inkubasi maka semakin cepat pula $F$. oxysporum menginfeksi xilem tanaman sehingga semakin panjang xilem diskolorasi. FMA bersimbiosis dengan akar tanaman dengan mengkolonisasi apoplast dan sel korteks (Pulungan, 2018). FMA menggunakan karbon hasil fotosintesis tanaman sehingga patogen tidak mendapatkan sumber makanan. Dengan demikian pertumbuhan patogen menjadi terhambat sehingga tanaman menjadi lebih tahan terhadap serangan patogen (Wicaksono et al., 2014; Aulia et al., 2016). Intensitas serangan penyakit pada tanaman yang diinokulasi FMA tergolong rendah (Tabel 2 dan Gambar 1). Hal ini karena FMA yang diinokulasikan terlebih dahulu telah aktif menginfeksi perakaran tanaman. Menurut Al-Hmoud dan Al-Momany (2015), untuk meningkatkan ketahanan tanaman dari serangan patogen dapat dilakukan melalui kolonisasi FMA terlebih dahulu, sehingga FMA mendominasi sistem perakaran. Akkopru dan Demir (2005), menambahkan tanaman yang terkolonisasi FMA sedikit mengalami kerusakan dan perkembangan patogen terhambat karena FMA mampu memperkuat ciri morfologi dan fisiologis tanaman dengan mengubah komposisi kimia jaringan tanaman.

Kolonisasi FMA pada akar tanaman dapat menyebabkan perubahan morfologi, seperti terjadinya lignifikasi pada bagian sel endodermis akar sehingga membentuk penghalang terhadap penetrasi patogen dan FMA menggantikan peran akar melalui hifa eksternalnya dalam penyerapan air serta unsur hara di dalam tanah. Selain itu peranan FMA dalam meningkatkan ketahanan tanaman dapat disebabkan oleh pengaruh ketahanan terimbas (Soenartiningsih, 2013). Tanaman mengalami perubahan metabolit, sebab. FMA mampu meningkatkan kandungan senyawa fenol pada akar tanaman, seperti flavonoid, isoflavonoid, dan tanin. Terjadinya akumulasi senyawa-senyawa fenol ini disebabkan karena meningkatnya aktivas enzim phenylalanine ammonium lyase (PAL) yang berfungsi dalam menginduksi ketahanan tanaman terhadap serangan patogen (Prasasti et al., 2013). Pernyataan ini didukung oleh Soenartiningsih (2013), tanaman jagung yang tidak diinokulasi FMA tidak terdeteksi adanya senyawa fenol, sedangkan tanaman yang diinokulasikan FMA mampu membentuk senyawa fenol.

\section{SIMPULAN}

Pemberian 200 g AMF setelah diinokulasikan F. oxysporum Schlecht et Fr. berpengaruh pada tinggi tanaman, jumlah daun, berat kering akar dan berat kering tajuk. Inokulasi $300 \mathrm{~g}$ AMF berpengaruh pada buah cabai, sedangkan pada persentase kolonisasi AMF semua perlakuan berbeda nyata dengan kontrol. Inokulasi $300 \mathrm{~g}$ AMF mampu menurunkan infeksi $F$. oxysporum Schlecht et Fr pada 30 HSI sebesar 3,36\%. 


\section{UCAPAN TERIMA KASIH}

Penulis mengucapkan terima kasih kepada Bapak Dr. Sang Ketut Sudirga, S.Si., M.Si., yang membantu dalam analisa statistik pada riset ini

\section{KEPUSTAKAAN}

Agrios GN. 2005. Plant Pathology. Edisi ke-5. Elsevier Academic Press: London.

Akaeze OO, Aduramigba-Modupe AO. 2017. Fusarium Wilt Disease of Tomato: Screening for Resistance and In-Vitro Evaluation of Botanical for Control: The Nigeria Case. Journal of Microbiology, Biotechnology and Food Sciences 7(1): 32-36.

Akkopru A, Demir S. 2005. Biological control of Fusarium Wilt in Tomato Caused by Fusarium oxysporum f.sp. lycopersici by AMF Glomus intraradices and some Rhizobacterial. Journal of Phytopathology 153: $544-550$.

Aktar MW, Sengupta D, Chowhury A. 2009. Review Article: Impact of Pesticides Use in Agriculture: Their Benefits and Hazards. Interdisc Toxicol Journal 2(1): 1-12.

Al-Hmoud G, Al-Momany A. 2015. Effect of Four Mycorrhizal Produsct on Fusarium Root Rot on Different Vegetable Crops. Journal of Plant Pathology and Microbiology 6(2): 1

Al-Askar AA, Rashad YM. 2010. Arbuskular Mycorrhizal Fungi: A Biocontrol Agent Common Bean Fusarium Root Rot Disease. Plant Pathology Journal 9: 31-38.

Aulia F, Susanti H, Fikri EN. 2016. Pengaruh Pemberian Pupuk Hayati dan Mikoriza terhadap Intensitas Serangan Penyakit Layu Bakteri (Ralstonia Solanacearum), Pertumbuhan, dan Hasil Tanaman Tomat. Jurnal Ziraa'ah 41(2): 250-260.

Brundrett M, Bougher N, Dell B, Grove T, Malajczuk N. 2008. Working with Mycorrhiza in Forestry and Agriculture. Australian center for Internasional Agricultural research: Canberra.
Campbell NA, Reece JN, Mitchell LG. 2002. Edisi Ke-5. Jilid 1. Erlangga: Jakarta.

Duriat AS, Gunaeni N, Wulandari AW. 2007. Penyakit Penting pada Tanaman Cabai dan Pengendaliannya. Pusat Penelitian dan Pengembangan Hortikultura. Badan Penelitian Tanaman Sayur.

Hakiki TN. 2013. Respon Pertumbuhan dan Produksi Kedelai (Glycine max L.) Merrill) yang Diberi Fungi Mikoriza Arbuskular pada Tanah Salin. Jurnal Online Agroteknologi 1(2): 421-427.

Hasanah U, Purnomowati, Dwiputranto U. 2017. Pengaruh Inokulasi Mikoriza Vesikula Arbuskula (MVA) Campuran terhadap Kemunculan Penyakit Layu Fusarium pada Tanaman Tomat (Solanum lycopersicum). Jurnal Scripta Biologica 4(1): 31-35.

Hasbiah ST, Wahidah BF. 2013. Perbandingan Kecepatan Fotosintesis pada Tanaman Sawi Hijau (Brassica juncea) yang diberi Pupuk Organik dan Anorganik. Jurnal Biogenesis 1(1): 61-69.

Imron M, Suryanti, Sulandari S. 2015. Peranan Jamur Mikoriza Arbuskular terhadap Perkembangan Penyakit Daun Keriting Kuning Cabai. Jurnal Perlindungan Tanaman Indonesia 19(2): 94-98.

Jamilah M, Purnomowati, Dwiputranto U. 2016. Pertumbuhan Cabai Mearah (Capsicum annuum L.) pada Tanah Masam yang Diinokulasi Mikoriza Vesikula Arbuskula (MVA) Campuran dan Pupuk Fospat. Jurnal Biosfera 33(1): 37-45.

Kementrian Pertanian. 2018. [cited 2019 March 19] Available from: URL: http://www.pertanian.go.id/home/?show=pa ge\&act= view\&id=61.

Masfufah R, Proborini MW, Kawuri R. 2016. Uji Kemampuan Spora Cendawan Mikoriza Arbuskula (AMF) Lokal Bali pada Pertumbuhan Tanaman Kedelai (Glycine max L.). Jurnal Simbiosis 4(1): 26-30.

Mila YN, Widnyana IK, Pandawani NP. 2016. Pengaruh Waktu Pemberian Pupuk Mikoriza Terhadap Pertumbuhan dan Hasil Tanaman 
Paprika (Capsicum annum var grossum L.). Jurnal Agrimeta 66-76.

Musfal. 2010. Potensi Cendawan Mikoriza Arbuskula untuk Meningkatkan Hasil Tanaman Jagung. Jurnal Litbang Pertanian 29(4): 154-158.

Prasasti OH, Purwani KI, Nurhatika S. 2013. Pengaruh Mikoriza Glomus fasciculatum Terhadap Pertumbuhan Vegetatif Tanaman Kacang Tanah yang Terinfeksi Patogen Sclerotium rolfsii. Jurnal Sains dan Seni Pomits 2(2): 74-78.

Proborini MW. 2011. Eksplorasi Jenis-jenis Endomikoriza Indigenus pada Lahan Kering di Bali dan Pemanfaatannya pada Pembibitan Mente (Anacardium ocidentale L.). Laporan Hibah Doktor. Universitas Udayana Denpasar. Bali.

Pulungan ASS. 2018. Tinjauan Ekologi Fungi Mikoriza Arbuskular. Jurnal Biosains 4(1): 17-22.

Putri AOT, Hadisutrisno B, Wibowo A. 2016. Pengaruh Inokulasi Mikoriza Arbuskular terhadap Pertumbuhan Bibit dan Intensitas Penyakit Bercak Daun Cengkeh. Jurnal Pemuliaan Tanaman Hutan 10(2): 145-154.

Setiadi Y. 2003. Arbuscular Mycorrhizal Inoculum Production. Program dan Abstrak Seminar dan Pameran. Teknologi Produksi dan Pemanfaatan Inokulan Endo Ektomikoriza untuk Pertanian, Perkebunan, dan Kehutanan: Bandung.
Sinaga SN. 2003. Ilmu Penyakit Hutan. Penebar Swadaya: Jakarta.

Smith SE, Read DJ. 2008. Mycorrhizal Symbiosis, 3rd Ed. San Diego :Academic Press.

Soenartiningsih. 2013. Potensi Cendawan Endimikoriza Arbuskular sebagai Media Pengendalian Penyakit Busuk Pelepah pada Jagung. Jurnal Iptek Tanaman Pangan 8(1): 48-53.

Triarta NA, Proborini MW, Hardini J. 2019. Peranan FMA Glomus sp. dan Pupuk Anorganik terhadap Produktivitas Tanaman Kedelai (Glycine max (L.) Merrill) var. Lokal Bali. Jurnal Mikologi Indonesia 3(2): 84-94.

Wandani SAT, Yuliani, Rahayu YS. 2015. Uji Ketahanan Lima Varietas Tanaman Cabai Merah (Capsicum annuum) terhadap Penyakit Tular Tanah (Fusarium oxysporum f. sp capsici). Jurnal Lentera Bio 4(3): 155160.

Windrasari L P., Proborini,M.W., Defiani, M.R., 2019. Biokontrol Endomikoriza terhadap jamur Curvularia sp.Penyebab Penyakit Tanaman Jagung (Zea mays L.). Simbiosis VII (1): 28-36.

Wicaksono MI, Rahayu M, Samanhudi. 2014. Pengaruh Pemberian Mikoriza dan Pupuk Organik terhadap Pertumbuhan Bawang Putih. Jurnal Ilmu-ilmu Pertanian 19(1): 3544. 